\title{
FLOOD MAGNITUDE AND FREQUENCY OF LITTLE TIMBER CREEK AT THE CULVERT ON INTERSTATE ROUTE 295 IN HADDON HEIGHTS TOWNSHIP, CAMDEN COUNTY, NEW JERSEY
}

U.S. GEOLOGICAL SURVEY

Open-File Report 96-321

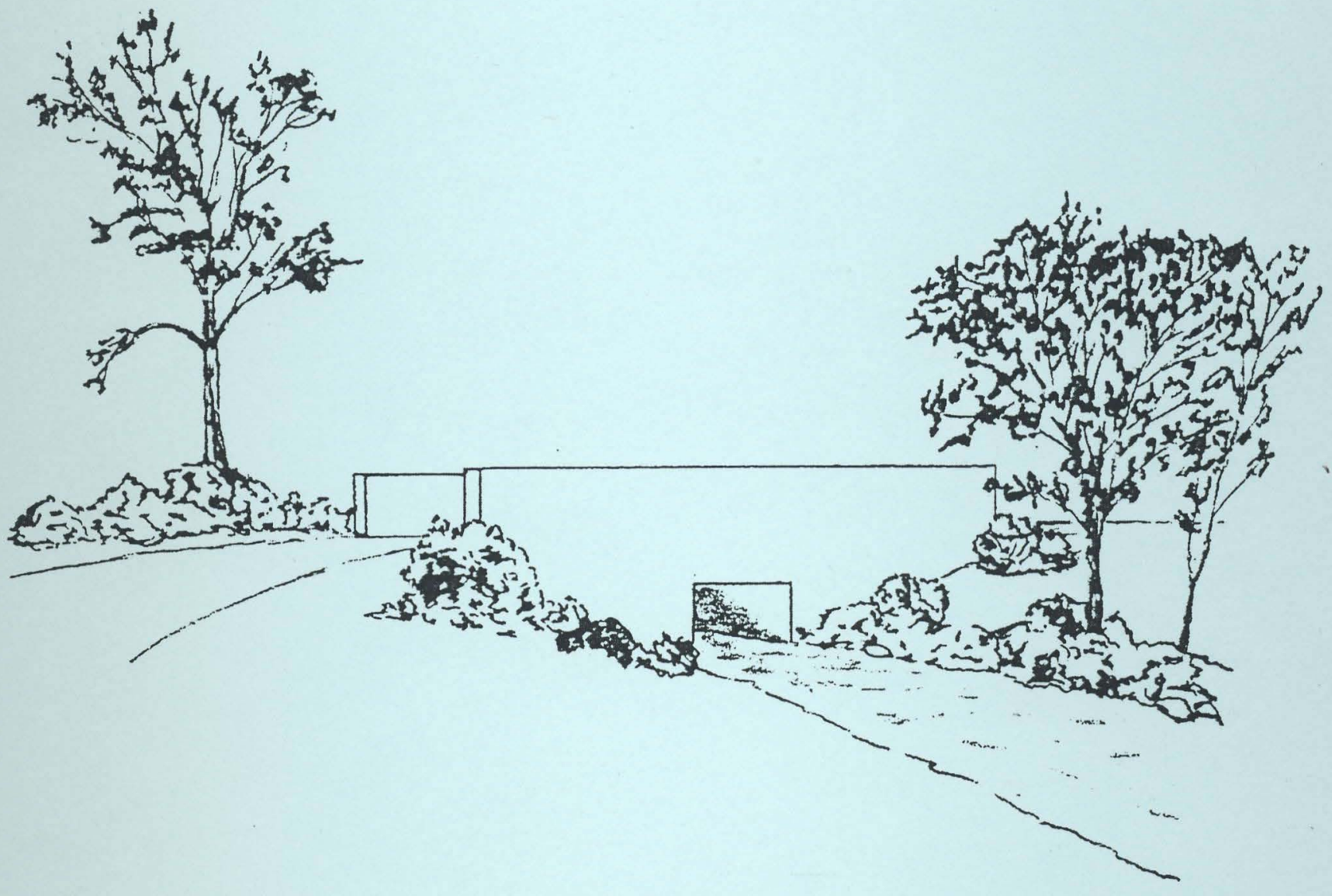

Prepared in cooperation with the

NEW JERSEY DEPARTMENT OF TRANSPORTATION

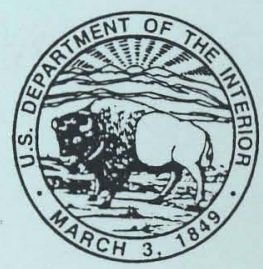




\section{FLOOD MAGNITUDE AND FREQUENCY OF LITTLE TIMBER CREEK AT THE CULVERT ON INTERSTATE ROUTE 295 IN HADDON HEIGHTS TOWNSHIP, CAMDEN COUNTY, NEW JERSEY}

By Thomas Barringer

U.S. GEOLOGICAL SURVEY

Open-File Report 96-321

Prepared in cooperation with the

NEW JERSEY DEPARTMENT OF TRANSPORTATION

West Trenton, New Jersey

1996 


\section{U.S. DEPARTMENT OF THE INTERIOR}

BRUCE BABBITT, Secretary

\section{U.S. GEOLOGICAL SURVEY}

Gordon P. Eaton, Director

For additional information write to:

\section{District Chief}

U.S Geological Survey

Mountain View Office Park

810 Bear Tavern Road, Suite 206

West Trenton, NJ 08628
Copies of this report can be obtained from:

U.S Geological Survey

Earth Science Information Center

Open-File Reports Section

Box 25286, MS 517

Denver Federal Center

Denver, CO 80225 


\section{CONTENTS}

Page

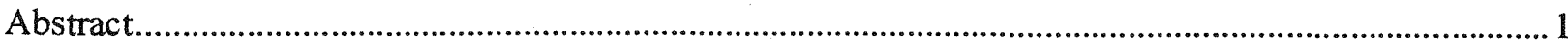

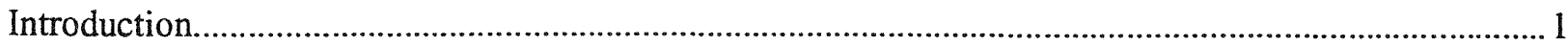

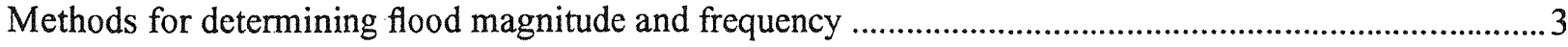

New Jersey Department of Environmental Protection Special Report 38 method....................................... 3

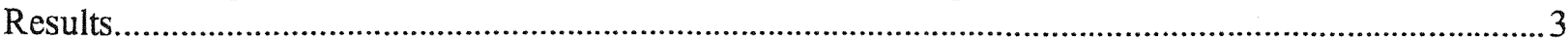

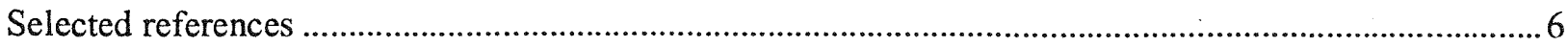

\section{ILLUSTRATIONS}

Figure 1. Map showing location of Little Timber Creek at the culvert at milepost 28.9 on Interstate Route 295 and associated drainage basin, Haddon Heights Township, New Jersey ....... 2

\section{TABLES}

Table 1. Explanatory variables for the flood-magnitude and -frequency analysis of Little Timber Creek at the culvert on Interstate Route 295, Haddon Heights Township, New Jersey ................. 4

2. Estimates of flood magnitudes for selected flood frequencies, Little Timber Creek at the culvert on Interstate Route 295, Haddon Heights Township, New Jersey ........................... 5 


\section{CONVERSION FACTORS}

Multiply

foot $(\mathrm{ft})$

mile (mi)

square mile $\left(\mathrm{mi}^{2}\right)$

foot per mile (ft/mi)

cubic foot per second $\left(\mathrm{ft}^{3} / \mathrm{s}\right)$
By

0.3048

1.609

2.590

0.189

0.0283
To obtain

meter

kilometer

square kilometer

meter per kilometer

cubic meter per second 


\title{
FLOOD MAGNITUDE AND FREQUENCY OF LITTLE TIMBER CREEK AT THE CULVERT ON INTERSTATE ROUTE 295 IN HADDON HEIGHTS TOWNSHIP, CAMDEN COUNTY, NEW JERSEY
}

\author{
By Thomas Barringer
}

\begin{abstract}
The magnitude and frequency of floods at Little Timber Creek at the culvert on Interstate Route 295, at milepost 28.9, in Haddon Heights Township, New Jersey, were determined by using the New Jersey Department of Environmental Protection Special Report 38 method. Flood-magnitude and -frequency estimates, as well as drainage-basin characteristics, are included in this report. The 100 -year-flood estimate is 770 cubic feet per second.
\end{abstract}

\section{INTRODUCTION}

Information on the magnitude and frequency of floods is critical to the planning and design of highway culverts and bridges. This information is not readily available for many stream crossings in New Jersey. To fulfill this information need, the U.S. Geological Survey (USGS), in cooperation with the New Jersey Department of Transportation, began an analysis of flood data for stream-crossing sites in New Jersey.

This report presents results of the analysis for Little Timber Creek at the culvert on Interstate Route 295 at milepost 28.9 in Haddon Heights Township, New Jersey. The culvert is located about midway between interchanges 28 and 29 of Interstate Route 295 in Haddon Heights Township New Jersey (fig. 1). The drainage area upstream from the site is calculated to be $1.61 \mathrm{mi}^{2}$. A field reconnaissance was performed on February 23, 1995, to verify the locations of the drainage-basin divides and basin characteristics. Because the direction of storm-sewer drainage in some parts of the basin is uncertain, the calculated drainage area is approximate.

The flood-insurance study for Lawnside Township (Federal Emergency Management Agency, 1978), in which part of the subject basin lies, does not include a detailed study of this stream. No flood data are available for Barrington Township or Haddon Heights Borough; therefore, flood discharges were not determined previously by this agency.

The U.S. Army Corps of Engineers (U.S. Army Corps of Engineers, 1969) analyzed streamflow for parts of the Little Timber Creek watershed downstream from the culvert. The Corps reports two types of flood discharges: the floodway-design flood and the standard-project flood. The floodway-design flood corresponds to the 100-year flood as estimated by the method of Stankowski (1974) (New Jersey Department of Environmental Protection, 1975). The standard-project flood is 1.25 times the floodway-design flood, roughly corresponding to the 500-year flood.

The site which is nearest the culvert and for which flood discharges are reported is at Bell Avenue in Bell Mawr/Mt. Ephraim (drainage area is $2.0 \mathrm{mi}^{2}$ ). At that site, estimated streamflow for the floodwaydesign flood was $500 \mathrm{ft}^{3} / \mathrm{s}$. The estimated streamflow for the standard-design flood is $850 \mathrm{ft}^{3} / \mathrm{s}$. 


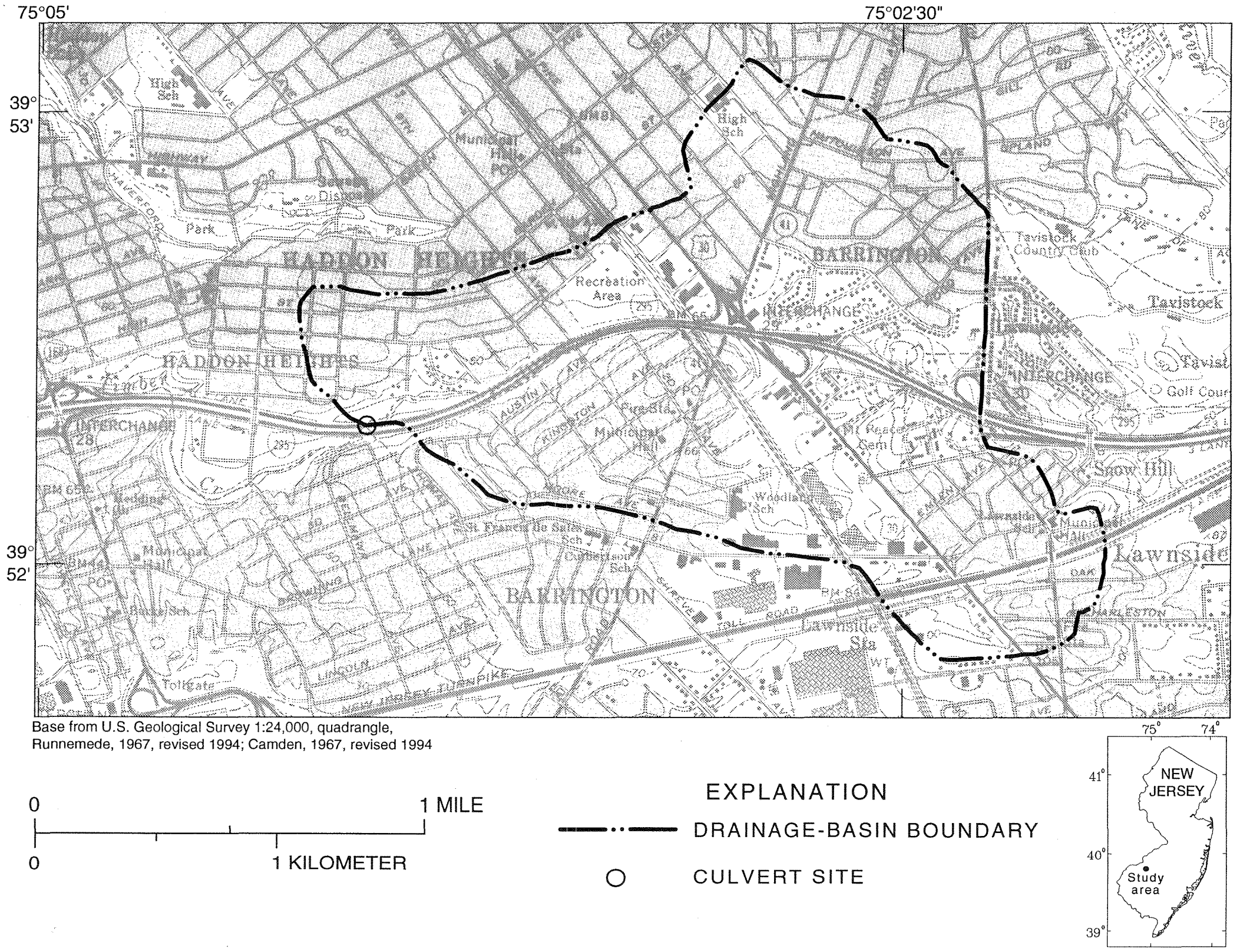

Figure 1. Location of Little Timber Creek at the culvert at milepost 28.9 on Interstate Route 295 and associated drainage basin, Haddon Heights Township, New Jersey. 


\section{METHODS FOR DETERMINING FLOOD MAGNITUDE AND FREQUENCY}

Various widely used methods for calculating flood magnitude and frequency were considered for use in determining the flood magnitudes that are likely to be exceeded at this site within a given number of years (recurrence interval). The rational method (Chow and others, 1988), New Jersey Department of Environmental Protection (NJDEP) Special Report 38 method (SR 38) (Stankowski, 1974), the U.S. Soil Conservation Service (SCS) Technical Release 55 (TR-55) method (U.S. Soil Conservation Service, 1986), the USGS transfer method (New Jersey Department of Environmental Protection, 1988), and the index-flood method (Thomas, 1964) were all considered for use in determining flood magnitude and frequency at the subject culvert.

\section{NEW JERSEY DEPARTMENT OF ENVIRONMENTAL PROTECTION SPECIAL REPORT 38 METHOD}

The SR 38 method (Stankowski, 1974) is suitable for the estimation of flood magnitudes at sites located in drainage areas greater than $1 \mathrm{mi}^{2}$; therefore, the SR 38 method is suitable for use for the subject site.

Flood-magnitude and -frequency estimates computed by using the SR 38 method were compared with estimates made by using the USGS transfer method. Estimates made with the USGS transfer method required the use of flood data from three streamflow-gaging stations located in basins that have drainage areas and other basin characteristics similar to those at the subject site. The stations are located within a 23-mi radius of the culvert.

Estimates of the 100-year flood at the subject site produced with the USGS transfer method were 1.1 and 1.2 times that of the SR 38 estimates made with flood data from two stations (South Branch Newton Creek at Haddon Heights, N.J., 01467317 and West Branch Cohansey River at Seeley, N.J., 01412500 , respectively) and 0.5 that of the SR 38 estimate made with flood data from a third station (Newton Creek at Collingswood, N.J., 01467305). The estimates made by using the SR 38 method agreed closely with the estimates made by using the USGS transfer method; therefore, the SR 38 estimate was chosen for this analysis.

\section{RESULTS}

Flood data from nearby streamflow or crest-stage gaging stations provide a good indication of the flood magnitude and frequency that can be expected at an ungaged site, particularly when drainage area and other basin characteristics are similar. In this study, estimates were obtained by using the NJDEP SR 38 method and were compared with estimates made by using the USGS transfer method.

The explanatory variabls used in applying the USGS transfer method for the culvert site are listed in table 1. The flood-magnitude and -frequency estimates made by using the SR 38 method are shown in table 2. The estimate of the 100-year flood discharge at the culvert site is $770 \mathrm{ft}^{3} / \mathrm{s}$.

The difference between the U.S. Army Corps of Engineers estimate of the floodway-design flood at Bell Avenue site $\left(500 \mathrm{ft}^{3} / \mathrm{s}\right)$ and the 100-year flood at the study site is attributed to differences in degree of basin development, increases in sewering and channelization, and improvements in methodology that have occurred in the 25 years since the floodway-design flood and standard-project flood studies were conducted. 
Table 1. Explanatory variables for the flood-magnitude and -frequency analysis of Little Timber Creek at the culvert on Interstate Route 295, Haddon Heights Township, New Jersey

Drainage area: 1.61 square miles

Latitude: $39^{\circ} 52^{\prime} 19^{\prime \prime}$

Longitude: $75^{\circ} 04^{\prime} 04^{\prime \prime}$

Highway: Interstate Route 295

Milepost: 28.9

U.S. Geological Survey 7-1/2-minute quadrangles: Camden, N.J.-Pa., Runnemede, N.J.

\begin{tabular}{llcl}
\hline \multicolumn{1}{c}{ Variable } & & Value & \multicolumn{1}{c}{ Unit } \\
\hline Drainage area & $=$ & 1.61 & square miles \\
Main-channel slope & $=$ & 29.9 & feet per mile \\
Surface-storage index & $=$ & 1.00 & percent \\
Total stream length & $=$ & 3740 & mile \\
Population density (1990) & $=$ & 25 & persons per square mile \\
Impervious cover & $=$ & 0.0 & percent \\
Lake and swamp area & & & percent \\
\hline
\end{tabular}


Table 2. Estimates of flood magnitudes for selected flood frequencies, Little Timber Creek at the culvert on Interstate Route 295, Haddon Heights Township, New Jersey

[Q, flood-magnitude estimates in cubic feet per second along with number, indicating recurrence-interval frequency in years; NJDEP SR, New Jersey Department of Environmental Protection Special Report]

Drainage area: 1.61 square miles

Latitude: $39^{\circ} 52^{\prime} 19^{\prime \prime}$

Longitude: $75^{\circ} 074^{\prime} 04^{\prime \prime}$

Highway: Interstate Route 295

Milepost: 28.9

U.S. Geological Survey 7-1/2-minute quadrangles: Camden, N.J.-Pa., Runnemede, N.J.

\begin{tabular}{lllllll}
\hline Estimating method & Q2 & Q5 & Q10 & Q25 & Q50 & Q100 \\
\hline NJDEP SR 38 & 204 & 296 & 391 & 526 & 631 & 770 \\
\hline
\end{tabular}




\section{SELECTED REFERENCES}

Chow, V.T., Maidment, D.R., and Mays, L.W., 1988, Applied hydrology: New York, McGraw-Hill, 572 p.

Federal Emergency Management Agency, 1978, Flood insurance study of the Borough of Lawnside, Camden County, New Jersey: Federal Emergency Management Agency, March 1978, 13 p.

New Jersey Department of Environmental Protection, 1975, Delineation of flood hazard areas, Raritan River Basin: New Jersey Department of Environmental Protection, 16 p. 7 pls.

New Jersey Department of Environmental Protection, 1988, Technical manual for stream encroachment: New Jersey Department of Environmental Protection, Division of Water Resources, Bureau of Floodplain Management, 151 p., 6 app.

Stankowski, S.J., 1974, Magnitude and frequency of floods in New Jersey with effects of urbanization: New Jersey Department of Environmental Protection Special Report 38, 46 p.

Thomas, D.M., 1964, Floods in New Jersey, magnitude and frequency: New Jersey Department of Conservation and Economic Development, Water Resources Circular 13, 145 p.

U.S. Army Corps of Engineers, 1969, Flood plain information Little Timber Creek, Camden County, New Jersey: U.S. Army Corps of Engineers, Philadelphia District, 34 p., 11 pls.

U.S. Soil Conservation Service, 1986, Urban hydrology for small watersheds: Engineering Division Technical Release 55, Washington, D.C., 162 p. 